\title{
Effects of $\alpha$-momorcharin on preimplantation development in the mouse
}

\author{
P. P. L. Tam, L. K. Law* and H. W. Yeung $\dagger$ \\ Departments of Anatomy, ${ }^{*}$ Obstetrics \& Gynaecology and $\dagger$ Biochemistry, The Chinese University of \\ Hong Kong, Shatin, N.T., Hong Kong
}

\begin{abstract}
Summary. When $\alpha$-momorcharin was injected intraperitoneally $(0.2 \mathrm{mg} / 25 \mathrm{~g}$ body weight) into pregnant mice on Days 1-3 of pregnancy, over $50 \%$ of the mice failed to support an implantation. In-vitro study of the effects of the protein on preimplantation embryos showed that the protein did not significantly disturb embryonic development from the 2-cell to compacting morula stage except when high concentrations $(\geqslant 0.5$ $\mu \mathrm{g} / \mathrm{ml}$ ) of protein were present. In many embryos, compaction of blastomeres was incomplete and subsequent blastocyst formation was impaired. Other protein-treated embryos that formed compacted morulae and early blastocysts later showed decompaction and degenerated. The protein-treated embryos generally had fewer numbers of cells because cell division beyond the morula stage was impaired. The poor development of morulae may be the cause of inhibition of early pregnancy in the mouse by $\alpha$-momorcharin.
\end{abstract}

\section{Introduction}

The basic glycoprotein $\alpha$-momorcharin has recently been isolated and purified from the seeds of Momordica charantia. This protein shows an inhibitory effect on pregnancy in the mouse during the implantation period (Law, Tam \& Yeung, 1983) and induces abortion during mid-gestation, i.e. Days 10-14 (unpublished observation). When compacted morulae and early blastocysts were exposed to this protein in vitro, development of the embryos beyond the blastocyst stage was impaired. The incidence of complete hatching from the zona pellucida and of successful attachment of the trophoblast to the plastic culture substrate both decreased. The extent to which trophoblast outgrew on the substrate also diminished. Inner cell mass development was less affected than the trophoblast. It was concluded that the in-vivo inhibition of implantation may be a consequence of the deleterious effect of $\alpha$-momorcharin on the trophoblast (Law et al., 1983). In the present study, we have investigated the effect of $\alpha$-momorcharin on the development of preimplantation embryos in vitro and attempted to correlate the results with the in-vivo inhibition of early pregnancy in the mouse.

\section{Materials and Methods}

$\alpha$-Momorcharin was isolated from the crude extract of decorticated seeds of Momordica charantia by acetone fractionation, and this fraction was further purified on CM Sepharose CL 6B and Sephadex G100 (fine) columns (Pharmacia, Uppsala, Sweden). The final preparation was tested for its abortifacient activity in pregnant mice at Days 4-14 of gestation and was shown to be 
chemically homogeneous by SDS-PA gel electrophoresis and immunoelectrophoresis. Preliminary analyses indicated that this protein has a molecular weight of 31000 , contains PAS-positive sugar moieties, carries aspartic acid in its $\mathrm{N}$-terminal sequence but no half-cystine and little methionine, and is separated as a basic molecule during electrophoresis.

Random bred ICR mice were caged with males overnight. The presence of vaginal plugs was checked the following morning (Day 1 of pregnancy). Pregnant mice were injected intraperitoneally with $\alpha$-momorcharin on Days 1-3 (see Table 1). The inhibitory effect of the protein on implantation was expressed as the percentage of non-pregnant animals per treatment.

Two-cell, 4-cell and compacting (8-16-cell) embryos were obtained from the oviducts of mice on Days 2-3 of pregnancy and the embryos were collected in PB1 solution (Whittingham \& Wales, 1969). The embryos were then washed once in fresh Medium 16 (Whittingham, 1971) and were cultured in groups of 5-10 in $0.5 \mathrm{ml}$ Medium 16 under $5 \% \mathrm{CO}_{2}$ in air. $\alpha$-Momorcharin was added in small volumes of phosphate-buffered saline to the culture medium. Embyros of different developmental stages were exposed to the protein either continuously or over a limited period in culture (see Tables $2 \& 3$ ). The embryos were examined under phase-contrast optics at $24-\mathrm{h}$ intervals for 3-4 days until most of the control embryos had reached the blastocyst stage. The cell number of pre-compaction cleavage-stage embryos was estimated by visual counting and that of morulae and blastocysts was determined on cell spreads prepared by the technique of Tarkowski (1966).

\section{Results}

Effect on early pregnancy in vivo

$\alpha$-Momorcharin given to mice on Days $1-3$ of pregnancy resulted in a significant reduction in the incidence of successful implantations at Day 8 (Table 1). The non-pregnant mice showed either a total absence of implantations or degeneration of all the implantations. Amongst the treated mice that remained pregnant the mean \pm s.e.m. number of implantation sites was $13.4 \pm 0.5(n=15)$ and this was close to the control value of $12.9 \pm 0.8(n=18$; not significantly different, $t$ test $)$.

Table 1. Effects of $\alpha$-momorcharin administered on Day

1-3 on the success of pregnancy in the mouse

\begin{tabular}{cccc}
\hline $\begin{array}{c}\text { Treatment } \\
(\mathrm{mg} / 25 \mathrm{~g} \\
\text { body wt) }\end{array}$ & $\begin{array}{c}\text { Day of } \\
\text { pregnancy at } \\
\text { treatment }\end{array}$ & $\begin{array}{c}\text { No. of } \\
\text { mice }\end{array}$ & $\begin{array}{c}\text { No. of non-pregnant } \\
\text { mice at Day 8 } \%)\end{array}$ \\
\hline $\begin{array}{c}0 \text { (saline } \\
\text { control) }\end{array}$ & $1-3$ & 21 & $3(14)$ \\
0.2 & 1 & 13 & $* 7(54)$ \\
0.2 & 2 & 9 & $* 7(78)$ \\
0.2 & 3 & 8 & $* 5(63)$ \\
\hline
\end{tabular}

${ }^{*} P<0.01$ compared with control value ( $\chi^{2}$ test).

\section{Effects on 2-cell embryos}

The development of 2-cell embryos to the compacted morula stage was little affected by $\alpha$ momorcharin (Table 2); $72-75 \%$ of the treated embryos cleaved to the 4-cell stage in the presence of 0.1 or $0.5 \mu \mathrm{g} \alpha$-momorcharin $/ \mathrm{ml}$. Only when the protein concentration reached $1.0 \mu \mathrm{g} / \mathrm{ml}, \mathrm{did} 49 \%$ of the embryos fail to cleave into 4-cell stages. The cell numbers of control and treated embryos were similar (Table 2). When 2-cell embryos were exposed to $\alpha$-momorcharin $(0 \cdot 1 \mu \mathrm{g} / \mathrm{ml})$ during the 2- to 4-cell stages, their subsequent development through cleavage, compaction and blastocyst 
formation was not retarded. However, when the period of treatment extended from the 2-cell to the compaction stage, development of embryos beyond the morula stage was impaired and $80 \%$ of embryos degenerated (Table 3). The cell number of these treated embryos $(14 \cdot 5 \pm 1.9, n=15)$ was significantly less $(P<0 \cdot 01, t$ test $)$ than that of the control embryos $(50 \cdot 8 \pm 3 \cdot 2, n=21)$ and cell division seemed to have been arrested at the compacting 16-cell stage. When 2-cell embryos were treated with higher concentrations of protein $(0 \cdot 5-1.0 \mu \mathrm{g} / \mathrm{ml})$ until they reached either the 4-cell stage or the compacting stage, fewer underwent complete compaction and none reached the blastocyst stage. All the treated embryos eventually decompacted and had degenerated by the end of culture.

Table 2. Effects of $\alpha$-momorcharin on the development of 2-cell stage mouse embryos after $24 \mathrm{~h}$ in vitro

\begin{tabular}{cccc}
\hline $\begin{array}{c}\alpha-\text { Momorcharin } \\
(\mu \mathrm{g} / \mathrm{ml})\end{array}$ & No. of embryos & $\begin{array}{c}\text { No. (\%) of embryos with } \\
\geqslant 1 \text { complete cleavage }\end{array}$ & $\begin{array}{c}\text { Mean } \pm \text { s.e.m. } \\
\text { cell no. of embryos } \\
\text { with } \geqslant 3 \text { cells } \dagger\end{array}$ \\
\hline 0 (control) & 210 & $157(75)$ & $4 \cdot 1 \pm 0 \cdot 1(192)$ \\
$0 \cdot 1$ & 50 & $36(72)$ & $4 \cdot 1 \pm 0 \cdot 1(46)$ \\
0.5 & 24 & $18(75)$ & $3.9 \pm 0 \cdot 1(20)$ \\
$1 \cdot 0$ & 65 & $33(51)$ & $3.9 \pm 0 \cdot 1(39)$ \\
\hline
\end{tabular}

$* P<0.01$ compared with control value $\left(\chi^{2}\right.$ test).

$\dagger$ No. of embryos in parentheses.

\section{Effects on 4-cell embryos}

A continuous presence of $\alpha$-momorcharin from the 4-cell stage onwards did not appear to affect the progression of development through cleavage stage to morula formation (Table 4a). However, compaction of blastomeres was incomplete in these treated embryos and isolated blastomeres that had been extruded from the embryos were frequently observed. Development from the morula to the blastocyst stage was impaired and at $72 \mathrm{~h}$, when $82 \%$ of control embryos had reached the fully expanded blastocyst stage (Pl. 1, Fig. 1), $>80 \%$ of the treated embryos had degenerated (P1. 1, Fig. $2)$. When 4-cell embryos were treated with $\alpha$-momorcharin $(0.1 \mu \mathrm{g} / \mathrm{ml})$ only during the precompaction stages, compaction of morulae was unaffected but significantly more embryos degenerated later and fewer managed to form blastocysts (Table $4 \mathrm{~b}$ ). The treated embryos had significantly $(P<0.01)$ fewer cells $(22.8 \pm 1.9, n=42$, for $0.1 \mu \mathrm{g} / \mathrm{ml} ; 12.3 \pm 2 \cdot 1, n=13$, for $0.5 \mu \mathrm{g} / \mathrm{ml})$ than did controls $(49 \cdot 2 \pm 2 \cdot 8, n=38)$. A more marked inhibitory effect on compaction and blastocyst formation was evident when $\alpha$-momorcharin was tested at $1 \mu \mathrm{g} / \mathrm{ml}$.

\section{Effects on compacting embryos}

A continuous exposure of the compacting 8-16-cell embryo to $\alpha$-momorcharin only slightly retarded compaction but markedly reduced the incidence of blastocyst formation (Table 4c). A similar effect was produced when $\alpha$-momorcharin was presented only for $24 \mathrm{~h}$ during which over $65 \%$ of embryos compacted fully. However, at $48 \mathrm{~h}$ these embryos had only one third of the normal cell number $(23.6 \pm 1 \cdot 9, n=13$, and $24 \cdot 3 \pm 1 \cdot 9, n=23$, respectively, compared with controls, 74.6 $\pm 5 \cdot 3, n=21 ; P<0.01$ for both), indicating that cell divisions beyond the morula stage were inhibited. When embryos were exposed to $\alpha$-momorcharin after most of them had compacted or were early blastocysts, about $40 \%$ of embryos degenerated during the next $24 \mathrm{~h}$ in culture. Fewer cells were found in these embryos $(41.0 \pm 2.6, n=20 ; P<0.01$ compared with controls), but this value was greater than those of the other two treatment groups. While about $80 \%$ of the control embryos reached the blastocyst stage after $72 \mathrm{~h}$ in culture, nearly all the treated embryos degenerated. 
P. P. L. Tam et al.

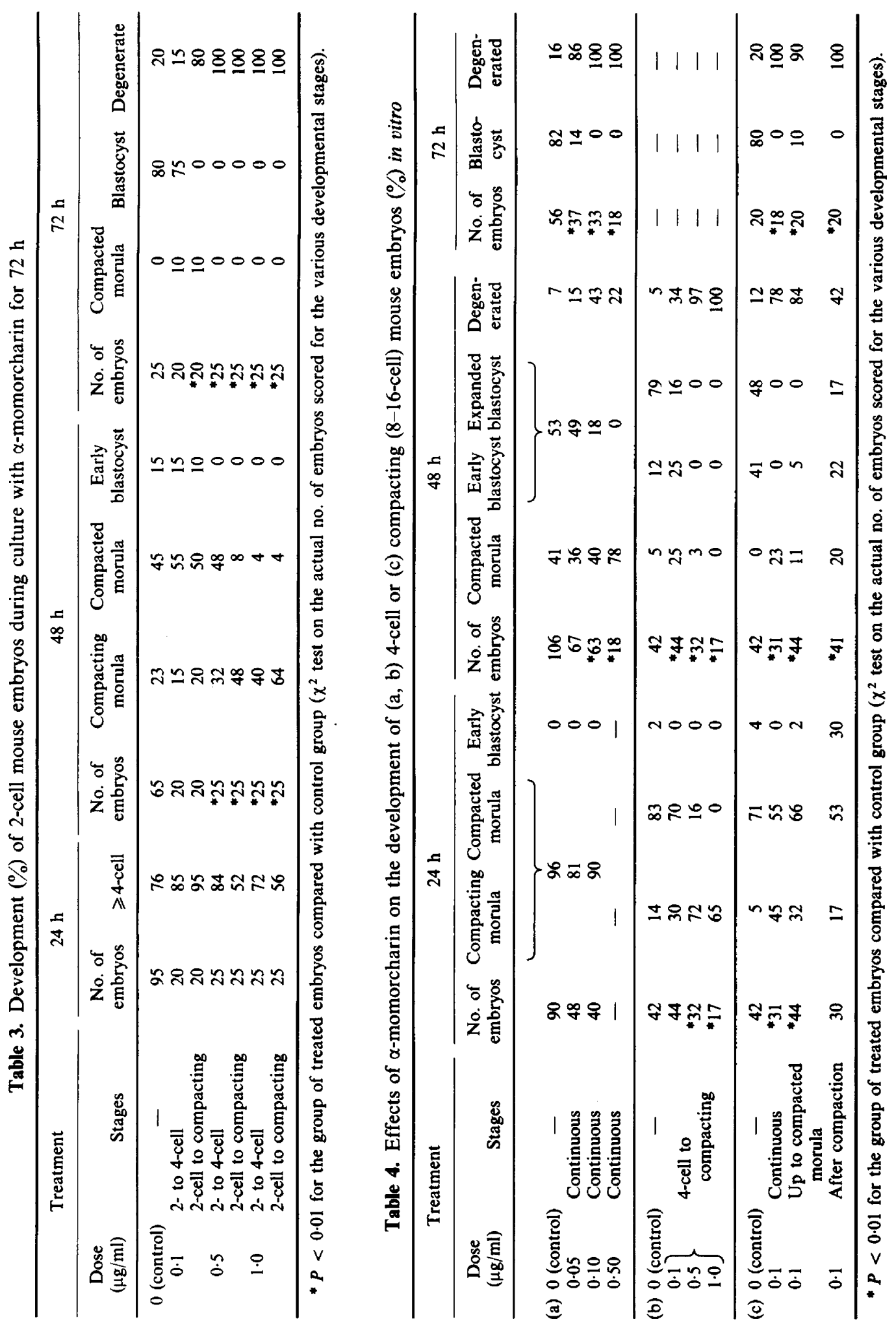



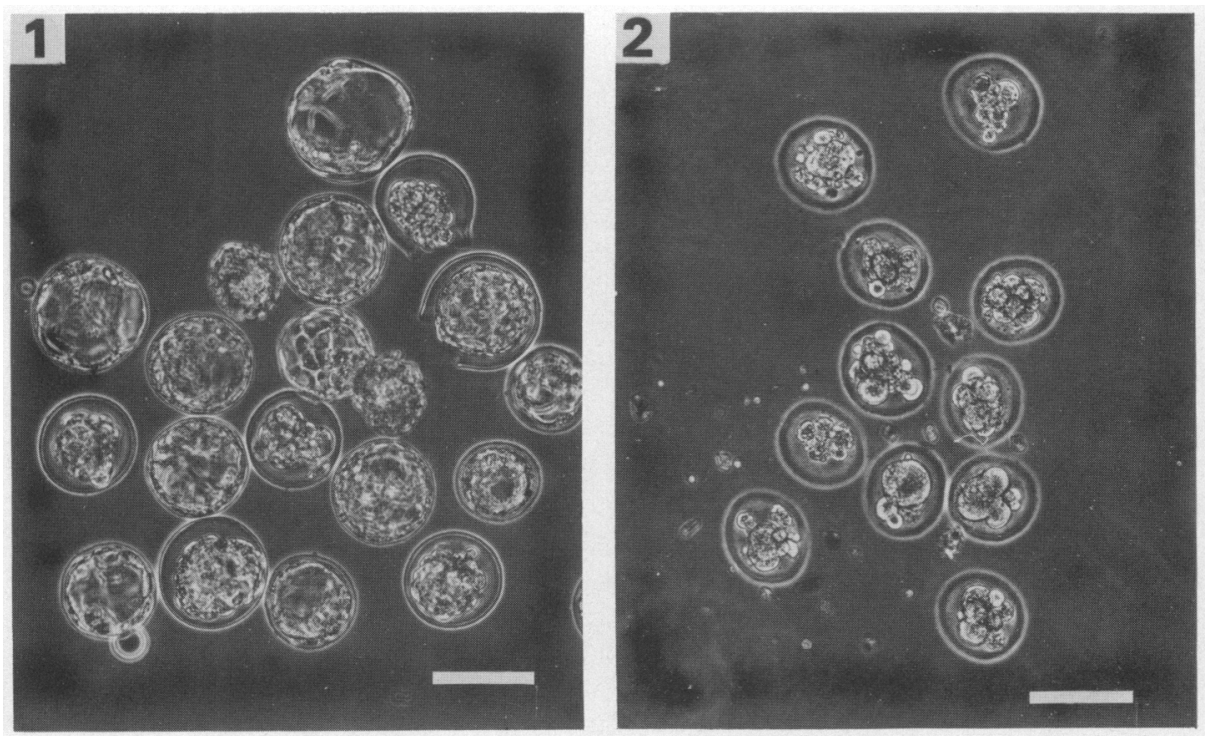

Fig. 1. Control embryos developed from the 4-cell stage for $72 \mathrm{~h}$. Some embryos were hatching from the zona pellucida. Bar $=100 \mu \mathrm{m}$.

Fig. 2. Partly decompacted and degenerating embryos developed from the 4-cell stage for $72 \mathrm{~h}$ in $0.5 \mu \mathrm{g} \alpha$-momorcharin $/ \mathrm{ml}$. Bar $=100 \mu \mathrm{m}$. 


\section{Discussion}

We have shown in this study that a single injection of $0.2 \mathrm{mg} \alpha$-momorcharin $/ 25 \mathrm{~g}$ body weight into pregnant mice on Days 1-3 resulted in an inhibition of pregnancy. This inhibitory effect in vivo is likely to be the result of a deleterious effect of the protein on the early development of the embryos. Our in-vitro observations indicated that the protein prevented the proper compaction of blastomeres into a morula and the $\alpha$-momorcharin-treated morulae failed to form normal blastocysts. Nearly all treated embryos degenerated at a time when the normal embryo showed an expansion of the blastocyst cavity and hatched from the zona pellucida. Experiments in which the pre-compacted embryos were exposed to $\alpha$-momorcharin for limited periods strongly suggested that (1) development through the first few cleavage divisions and initial compaction was unaffected by the protein and (2) the defects in compaction and blastocyst formation were manifestations of a subtle deleterious effect imposed by the protein at earlier stages. The possibility that an 'inhibitory' concentration of $\alpha$-momorcharin may persist in the pregnant mouse until the embryos reach the most susceptible transition stage of morula-blastocyst cannot be excluded until the pattern of disposition of the protein is known. Much less $\alpha$-momorcharin was required to produce an inhibitory effect on 4-cell or compacting embryos than on 2-cell embryos.

A common feature in the response of the pre-compacted embryo to various inhibitors of nucleic acid and protein synthesis is that continuous treatment during the cleavage to morula stages tends to disturb compaction, blastocyst formation and embryonic viability. Treatment of the embryo at stages of transition from morula to blastocyst tends to affect the differentiation of the inner cell mass and the trophectoderm of the blastocyst (Thomson \& Biggers, 1966; Skalko \& Morse, 1969; Tasca \& Hillman, 1970; Sherman \& Atienza, 1975; Rowinski, Solter \& Koprowski, 1975; Pedersen \& Spindle, 1977; Spielmann \& Jacob-Muller, 1981). Law et al. (1983) have demonstrated an impairment of the subsequent differentiation capacity of the trophoblast. $\alpha$-Momorcharin may also interact with other cell surface glycoproteins on the blastomere and adversely affect compaction. When normal glycosylation of cell membrane protein was inhibited by tunicamycin, the embryos either remained uncompacted or initially underwent partial compaction and later decompaction (Surani, 1979; Surani, Kimber \& Handyside, 1981). This is reminiscent of the behaviour of $\alpha$-momorcharin-treated embryos.

$\alpha$-Momorcharin has an abortifacient property similar to that of $\alpha$-trichosanthin in the periimplantation period and mid-gestation in the mouse (Chang, Saksena, Lau \& Wang, 1979; Zhou, Li, Shu, Bao \& Chu, 1982; Law et al., 1983). There are, however, very few studies on the effect of these two proteins on preimplantation development. Chang et al. (1979) could not observe any effect of $\alpha$-trichosanthin on pregnancy in mice treated on Days $1-4$, while Zhou et al. (1982) found a definite abortifacient effect of $\alpha$-trichosanthin in mice during the implantation period. Ultrastructural evidence of cellular damage has been found in the rabbit blastocyst exposed to trichosanthin in vitro (Tseng, Teng, Wu \& Chou, 1979). Our study is the first to demonstrate the inhibitory effect of an abortifacient plant protein on preimplantation development in the mouse.

\section{References}

Chang, M.C., Saksena, S.K., Lau, I.F. \& Wang, Y.H. (1979) Induction of mid-term abortion by trichosanthin in laboratory animals. Contraception 19, 175184.

Law, L.K., Tam, P.P.L. \& Yeung, H.W. (1983) Effects of $\alpha$-trichosanthin and $\alpha$-momorcharin on the development of peri-implantation mouse embryos. J. Reprod. Fert. 69, 597-604.

Pedersen, R.A. \& Spindle, A.I. (1977) Interference with in vitro development of mouse inner cell mass by $24-\mathrm{h}$ treatment with 5-bromodeoxyuridine. Differentiation 9, 43-48.

Rowinski, J., Solter D. \& Koprowski, H. (1975) Mouse embryo development in vitro: effects of inhibitors of RNA and protein synthesis on blastocyst and postblastocyst embryos. J. exp. Zool. 192, 133-142.

Sherman, M.I. \& Atienza, S.B. (1975) Effects of bromodeoxyuridine, cytosine arabinoside and colcemid upon in vitro development of mouse blastocysts. J. Embryol. exp. Morph. 4, 467-484. 
Skalko, R.G. \& Morse, J.M.D. (1969) The differential response of the early mouse embryo to actinomycin D treatment in vitro. Teratology 2, 47-54.

Spielmann, H. \& Jacob-Muller, U. (1981) Investigations on cyclophosphamide treatment during the preimplantation period. II. In vitro studies on the effects of cyclophosphamide on its metabolites 4-OH-cyclophosphamide, phosphamide mustard and acrolein on blastulation of four-cell and eight-cell and eight-cell mouse embryos and their subsequent development during implantation. Teratology 23, 7-13.

Surani, M.A.H. (1979) Glycoprotein syntheis and inhibition of glycosylation by tunicamycin in preimplantation mouse embryos: compaction and trophoblast adhesion. Cell 18, 217-227.

Surani, M.A.H., Kimber, S.J. \& Handyside, A.H. (1981) Synthesis and role of cell surface glycoproteins in preimplantation mouse development. Expl Cell Res. 133, 331-339.

Tarkowski, A.K. (1966) An air drying method for chromosome preparations from mouse eggs. Cytogenetics 5, 394-400.
Tasca, R.J. \& Hillman, N. (1970) Effects of actinomycin $D$ and cycloheximide on RNA and protein synthesis in cleavage stage mouse embryos. Nature, Lond. 225, 1022-1025.

Thomson, J.L. \& Biggers, J.D. (1966) Effects of inhibitors of protein synthesis on the development of preimplantation mouse embryos. Expl Cell Res. 41, 411-427.

Tseng, M.P., Teng, M.Y., Wu, H.L. \& Chou, M.Y. (1979) Electron microscopic observations on the effect of trichosanthin to blastocyst. Acta biol. exp. sin. 12, 266-269. (In Chinese.)

Whittingham, D.G. (1971) Culture of mouse ova. $J$. Reprod. Fert., Suppl. 14, 7-22.

Whittingham, D.G. \& Wales, R.G. (1969) Storage of 2-cell mouse embryos in vitro. Aust. J. biol. Sci. 22, 10651068.

Zhou, M.H., Li, Q., Shu, H.D., Bao, Y.M. \& Chu, Y.H. (1982) Pharmacological study of the effect of radix triochosanthin on terminating early pregnancy. Acta pharm. sin. 17, 176-181.

Received 23 June 1983 